\title{
TONALITE-HOSTED EARLY PROTEROZOIC GOLD DEPOSIT AT OSIKONMÄKI, SOUTHEASTERN FINLAND
}

\author{
OLAVI KONTONIEMI and ELIAS EKDAHL
}

\begin{abstract}
KONTONIEMI, OLAVI and EKDAHL, ELIAS, 1990. Tonalite-hosted early Proterozoic gold deposit at Osikonmäki, southeastern Finland. Bull. Geol. Soc. Finland 62, Part 1, 61-70.

The Osikonmäki gold deposit is hosted by an early Proterozoic tonalite close to the Archean-Proterozoic boundary along the Raahe-Ladoga suture zone. The structure, petrology and chemistry of the Osikonmäki intrusion are typical of synkinematic I-type granitoids having calc-alkaline affinity.

The deposit was discovered by boulder tracing and is situated in a deformed shear zone. Gold is concentrated in open $\mathrm{F} 3$ synforms plunging 20 degrees to the ESE. The dominant ore minerals are pyrrhotite, arsenopyrite, löllingite and chalcopyrite, occurring as disseminations or in places as compact veins and stringers.

Gold occurs as native gold and electrum in both sulphide and silicate phases and is invariably accompanied by Bi-bearing minerals with variable Se and Te contents. The measured mineral resources in the eastern part of the shear zone are 2 Mt at $3 \mathrm{~g} / \mathrm{t} \mathrm{Au}$ and $0.77 \%$ As.

Mineralogical and geochemical alteration is limited to the sheared and mineralized zone itself, manifested by biotitization, weak silicification and potassic alteration.
\end{abstract}

Key words: gold ores, igneous rocks, tonalite, chemical composition, ore minerals, Proterozoic, Finland, Rantasalmi, Osikonmäki.

Olavi Kontoniemi and Elias Ekdahl: Geological Survey of Finland, Exploration Department, P.O.Box 1237, 70701 Kuopio, Finland.

\section{Introduction}

The Osikonmäki occurrence is located in southeastern Finland in the parish of Rantasalmi (Fig. 1) and lies in the transition zone between the Svecofennian and Karelian schist belts. Both these belts belong to the Svecokarelides and represent different types of volcanic-sedimentary associations of the same orogenic cycle (Simonen 1980).

The study area also falls within the RaaheLadoga main sulphide ore belt of Finland (Kahma 1973). Although the belt has also been a tar- get for gold prospecting during recent years, only minor, uneconomical deposits have so far been found.

The Quaternary geology is well known in this part of Finland. The bedrock is till covered and the landscape is dominated by drumlins with the direction of glacial transport consistently from northwest to southeast. Boulder tracing has been the main method employed in reconnaissance work.

Gold and a weak sulphide dissemination are connected with the marginal area of tonalitic bodies. Magnetic, electromagnetic and IP mea- 


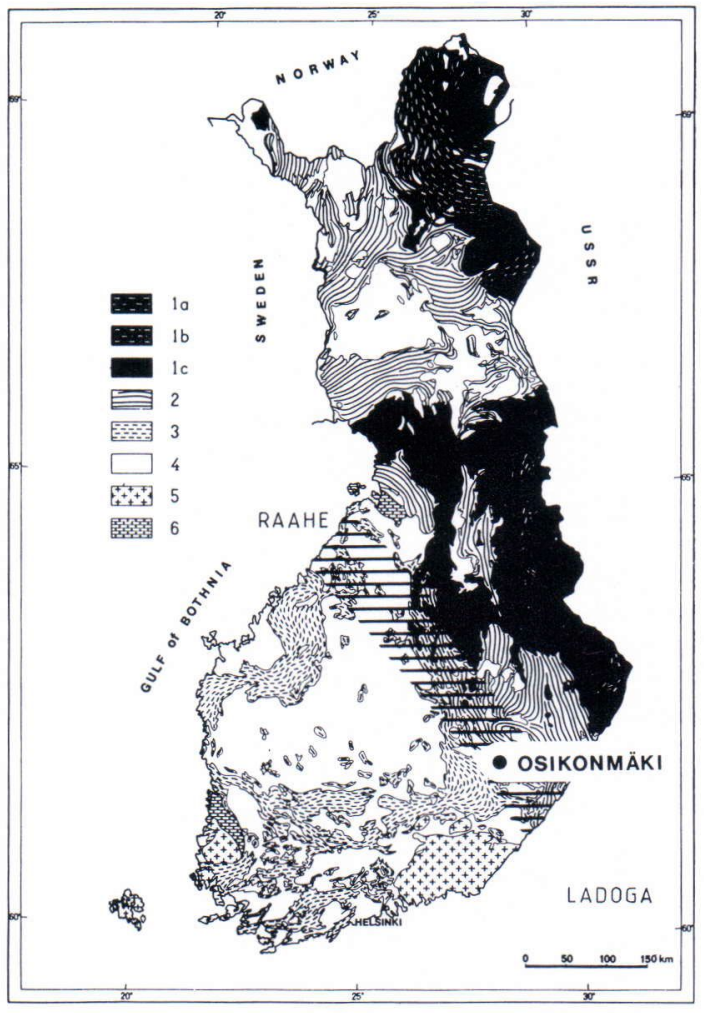

Fig. 1. Location of the Osikonmäki occurrence in SE-Finland. The Raahe-Ladoga sulphide ore belt is marked by horizontal lines. Main structural units of the Precambrian in Finland after Simonen (1980). Pre-svecokarelidic: 1a = schist and paragneiss; $1 \mathrm{~b}=$ granulite; $1 \mathrm{c}=$ orthogneiss. Svecokarelidic: 2 = Karelidic schist belt; 3 = Svecofennidic schist belt; 4 = orogenic plutonic rocks. Post-svecokarelian: 5 = rapakivi granites; $6=$ Jotnian sediments.

surements have been used successively in the follow-up stages. Mineralized bedrock has finally been localized by detailed till/bedrock interface geochemistry and diamond drilling.

Development in rapid analytical methods has been essential for gold prospecting. Gold in ore boulders, rock and till samples was analyzed by GAAS and in drill cores by fire assay method (sample $30 \mathrm{~g}$ ). Whole rock analyses were made by XRF.

\section{Regional geology}

The bedrock of the Osikonmäki area consists mainly of granitoids and supracrustals including both metasedimentary and metavolcanic rocks (Fig. 2). Small granite stocks and pegmatite dykes also occur. Metasedimentary rocks are mainly greywackes with some calc-silicate and black schist intercalations. Metavolcanics consist of felsic and intermediate pyroclastic rocks, amphibolites and ultramafic rocks. Amphibolites are dominantly pillow lavas and pyroclastic breccias ranging from tholeiitic basalts (amphibolites) to komatiitic basalts in composition (Kousa 1985). Korsman et al. (1984) have pointed out that the progressive metamorphism in the RantasalmiSulkava area resembles metamorphism in a tectonically thickened crust. The metapelites are characteristed by well developed metamorphic zoning, with grade increasing up to granulite facies towards the Sulkava thermal dome which is centred about $30 \mathrm{~km}$ south of Lake Kolkonjärvi. Five metamorphic zones have been recognized: andalusite-muscovite zone, potassium feldspar-sillimanite zone, potassium feldsparcordierite zone, garnet-cordierite-biotite zone and garnet-cordierite-sillimanite zone (Korsman et al. 1984; Korsman and Kilpeläinen 1986). The Osikonmäki area is located in the potassium feldspar-sillimanite zone.

The structural geology is complicated. This area belongs to the long Raahe-Ladoga suture zone representing an early Proterozoic continental margin of Circum Pacific-type with a hypothetical subduction on oceanic crust towards east (Gaál 1986). The Kolkonjärvi lineament is one of several subparallel, NW-SE trending, mostly dextral transcurrent faults (Korsman et al. 1984 and Gaál 1985). Korsman and Kilpeläinen (1986) have distinguished four successive deformation phases in the Rantasalmi-Sulkava metapelite area. S1-schistosity is very weak and the angle between $\mathrm{S} 1$ and bedding is small. Bedding and Dl structures are deformed by isoclinal F2 folds with a wave length of several 


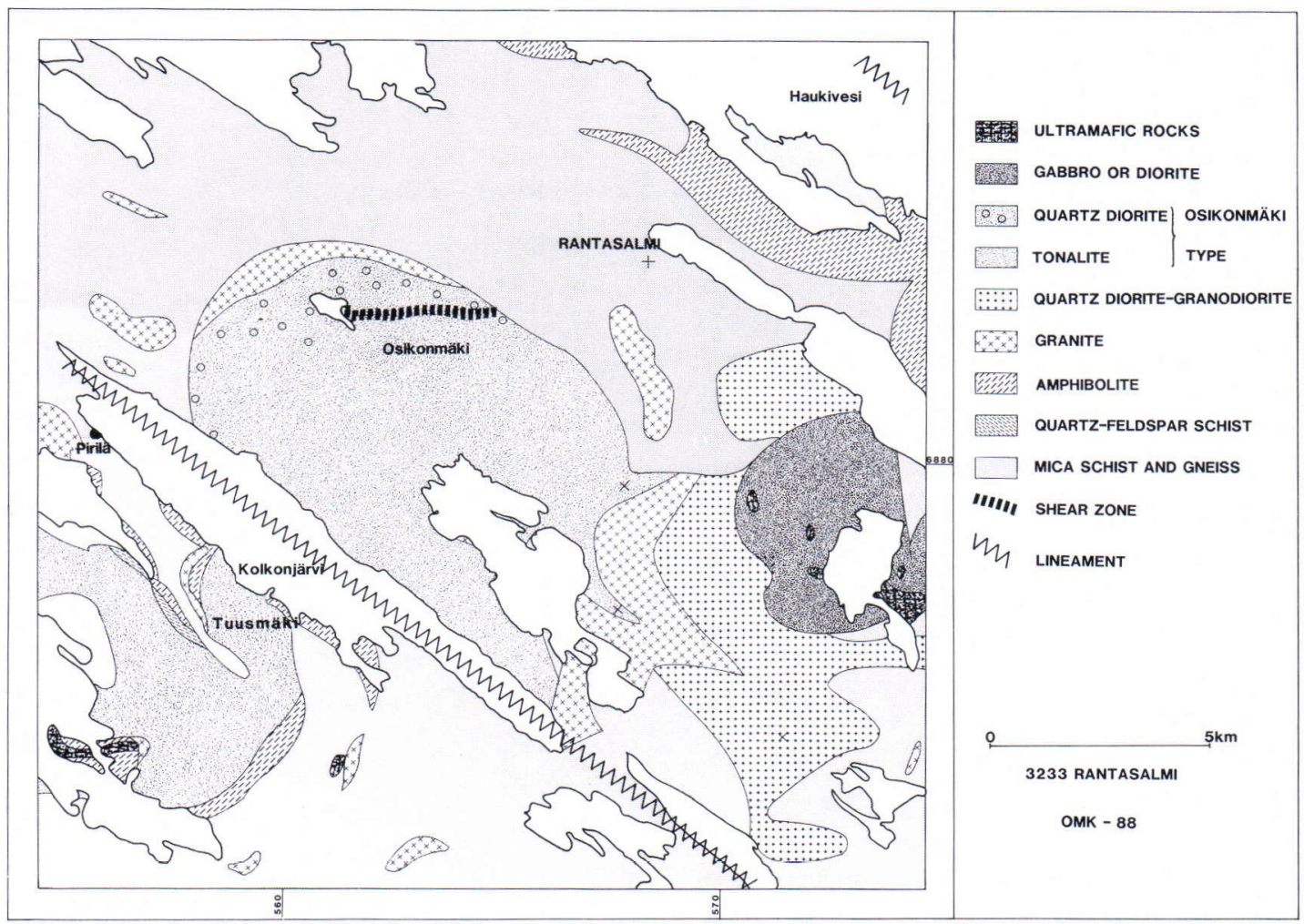

Fig. 2. Regional geological map of the Osikonmäki area, partly after Korsman (1973).

hundreds of metres. The intensity of S2-schistosity increases with the growth in metamorphic grade. Sillimanite porphyroblasts have crystallized during D2 and were deformed during D3. The asymmetric $\mathrm{F} 3$ folds of various sizes have been deformed by D4, which is expressed as a crenulation.

Tonalite intrusions in this area have a distinctly gneissose character. According to Korsman et al. (1984), similar structural elements and the same metamorphic events as recorded in the metapelites indicate the premetamorphic character of the Tuusmäki tonalite west of Lake Kolkonjärvi (Fig. 2) in relation to progressive metamorphism. U$\mathrm{Pb}$ dating of zircons give an age of $1888 \pm 15 \mathrm{Ma}$ for the Tuusmäki tonalite.

In addition to the Osikonmäki occurrence there are also gold occurrences controlled by stratigraphy and tectonism in supracrustals of Pirilä area. These occurrences are situated in a transitional zone between the volcanic and sedimentary units. The biggest occurrence, Pirilä (Fig. 2), has ore reserves of $150000 \mathrm{t}$ with an average grade of $8 \mathrm{~g} / \mathrm{t} \mathrm{Au}$ and $30 \mathrm{~g} / \mathrm{t} \mathrm{Ag}$ (Makkonen and Ekdahl 1988).

\section{Osikonmäki intrusion}

The Osikonmäki intrusion is about $50 \mathrm{~km}^{2}$ in areal extent and is structurally and petrologically analogous to the Tuusmäki tonalite described by Korsman et al. (1984). The contacts of the roundish intrusion are regionally concordant with the supracrustals. Inclusions of supracrustals are typical in the contact area. Tourmaline-bearing 
pegmatites are usually abundant in supracrustals near the contact area, but no clear contact metamorphic influence has been observed.

The core of the intrusion consists mainly of equigranular tonalite or granodiorite and the marginal phase of quartz diorite (Fig. 2). The contacts between the phases are gradual and intrusive breccias between different rock types are absent. Euhedral to subhedral plagioclase phenocrysts (5-10 $\mathrm{mm}$ in size) locally give the rock a porphyritic appearance. Modal compositions of the granitoid phases near by the gold occurrence described on QAP-diagram are given in Fig. 3.

The marginal quartz diorite is clearly oriented and in places gneissose, having granulated or even granoblastic texture. The major rock-forming minerals are plagioclase (andesine), quartz and biotite and accessory minerals are diopside, hornblende, opaques, titanite, apatite, zircon and occasionally potassium feldspar.

Tonalite and granodiorite have more or less hypidiomorphic and in places weakly porphyritic texture. Plagioclase (oligoclase), quartz, biotite and in varying amounts potassium feldspar (microcline) are major minerals while hornblende, opaques, titanite, apatite and zircon are typical accessory minerals.

Deformed aplite veins occur in the vicinity of the deposit in particular, whereas younger granite dykes and thin quartz veins cut both the mineralized rock and the country rock.

Chemically the granitoids are of calc-alkaline affinity and they have slight variations in $\mathrm{CaO} /\left(\mathrm{K}_{2} \mathrm{O}+\mathrm{Na}_{2} \mathrm{O}\right)$ and $\mathrm{K}_{2} \mathrm{O} / \mathrm{Na}_{2} \mathrm{O}$ (Fig. 3). The low $\mathrm{K} / \mathrm{Na}$ ratios and the mol. $\mathrm{Al}_{2} \mathrm{O}_{3} /(\mathrm{CaO}+$ $\mathrm{Na}_{2} \mathrm{O}+\mathrm{K}_{2} \mathrm{O}$ ) ratios varying between 0.869 and 1.056 indicate the I-type character of the magma (Nurmi et al. 1984).

The investigations in the Tuusmäki area by Korsman et al. (1984) and the geochemical features indicate that the Osikonmäki intrusion belongs to the synkinematic I-type granitoids according to the classification scheme of Pro- terozoic granitoids in Finland described by Nurmi and Haapala (1986).

\section{Osikonmäki deposit}

The gold occurrence was discovered by boulder tracing. Over 200 analyzed boulders revealed much about the mode of occurrence and possible Au contents. About 60 samples had Au contents over $1 \mathrm{ppm}$ and the highest value determined was $103.8 \mathrm{ppm}$ from a boulder situated just above the occurrence. Typically the boulders have some arsenopyrite and a clear indication of shearing.

The only economically important metal in the Osikonmäki occurrence is $\mathrm{Au}$. In the drillings conducted so far, bore hole 421 (Fig. 4) has the best ore section, situated at a depth of 183.00$208.00 \mathrm{~m}$ (drilling angle $53^{\circ}$ ). The average $\mathrm{Au}$ content over $25 \mathrm{~m}$ is $9.5 \mathrm{ppm}$ and the highest content is $23.2 \mathrm{ppm}(188.00-189.00 \mathrm{~m})$. In the best explored eastern part of the shear zone (Osikko 1, Fig. 4) measured mineral resources are $4 \mathrm{Mt}$ at $2 \mathrm{~g} / \mathrm{t} \mathrm{Au}$ (cut off $0.5 \mathrm{~g} / \mathrm{t}$ ) and $2 \mathrm{Mt}$ at $3 \mathrm{~g} / \mathrm{t}$ (cut off $1.0 \mathrm{~g} / \mathrm{t}$ ), respectively. In the second case an average As content is $0.77 \%$.

\section{Mode of occurrence}

The Osikonmäki occurrence is a shear-zonehosted gold deposit situating in the northern part of the intrusion. The W-E-trending shear zone (Fig. 2) is at least $3 \mathrm{~km}$ long dipping gently to the south. The width of the gold-bearing zone ranges from $2-3 \mathrm{~m}$ to $15-20 \mathrm{~m}$, but small scale shearing also occurs outside the major zone.

The sheared host rock has a foliated, granoblastic texture and an altered mineralogy. Quartz, microcline, biotite and oligoclase are major minerals and diopside, epidote, carbonate, titanite, apatite and zircon are typical accessory minerals.

The block diagram (Fig. 4) shows a possible structural control of the mineralization. The 

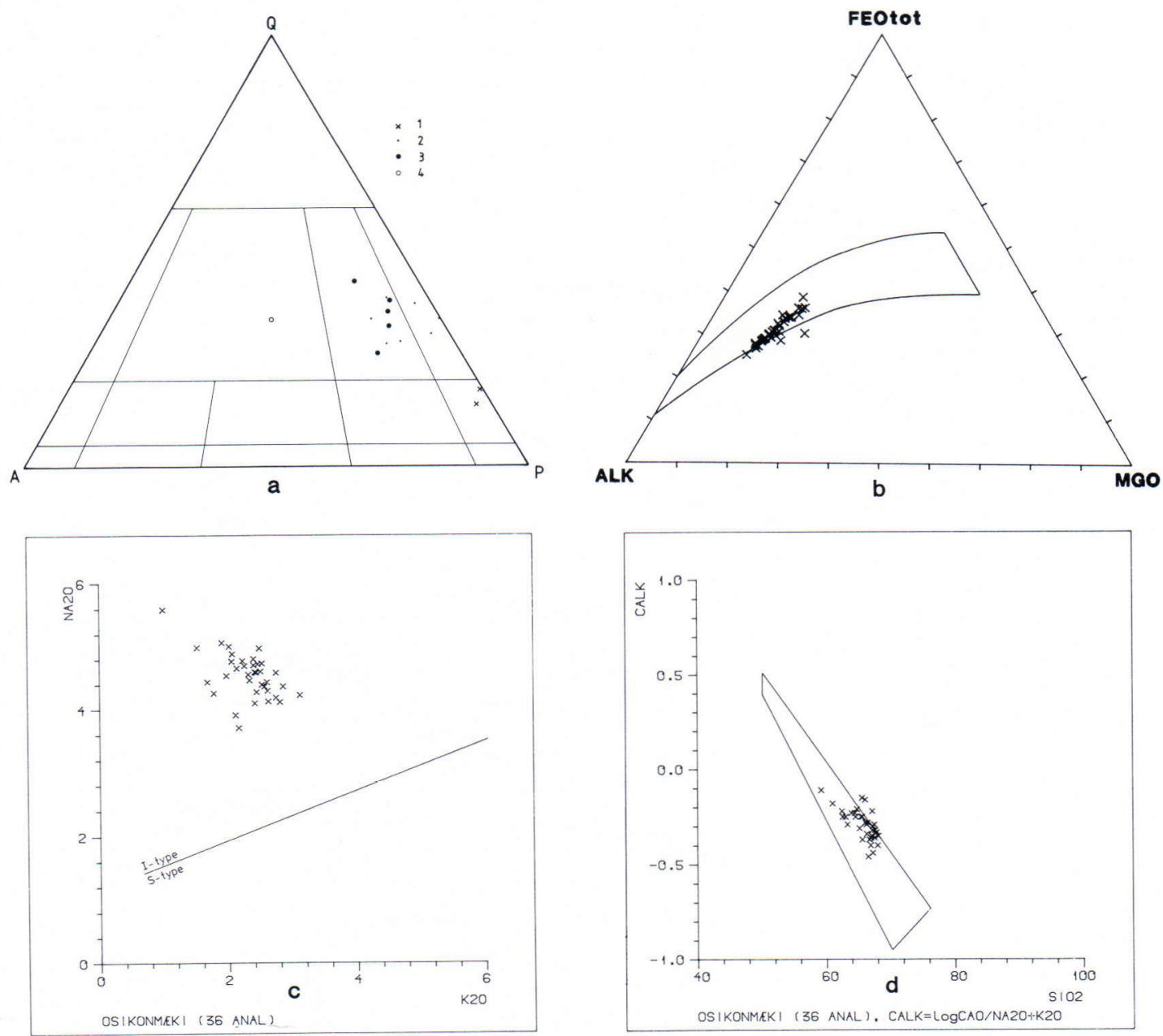

Fig. 3. Modal and chemical compositions of the Osikonmäki intrusion. a) Modal compositions presented on the QAP diagram of Streckeisen (1974), 500 points per thin section. 1 = quartz diorite, $2=$ tonalitic or granodioritic host rock, $3=$ mineralized rock, 4 = granite dyke. b) AFM diagram $(n=36)$. Delimited area represents the field of certain calc-alkaline island arc volcanites after Ringwood (1974). c) $\mathrm{Na}_{2} \mathrm{O}-\mathrm{K}_{2} \mathrm{O}$ diagram $(\mathrm{n}=36)$. The I-type/S-type line is after White and Chappell (1983). d) Calc-alkali ratio-silica diagram $(n=36)$. Delimited area represents the field of modern calc-alkaline andesites after Brown (1982).

sheared gold-bearing horizons have been shortened by large and small scale left-hand folding especially in the eastern part of the zone. Au has been concentrated in gentle F3 synforms plunging about 20 degrees to the ESE. Some gold-bearing compact arsenopyrite veins and quartz veins have been formed on the F3 axial plane. Thus it is obvious that the shear zone has been metamorphosed and deformed during the D3 phase, which was active 1830-1810 Ma ago (Korsman et al. 1988).

\section{Ore mineralogy}

In many places both the tonalitic rock and the quartz diorite in the contact zone have weak and inhomogenous disseminations of pyrrhotite, chalcopyrite and occasionally some arsenopyrite, 


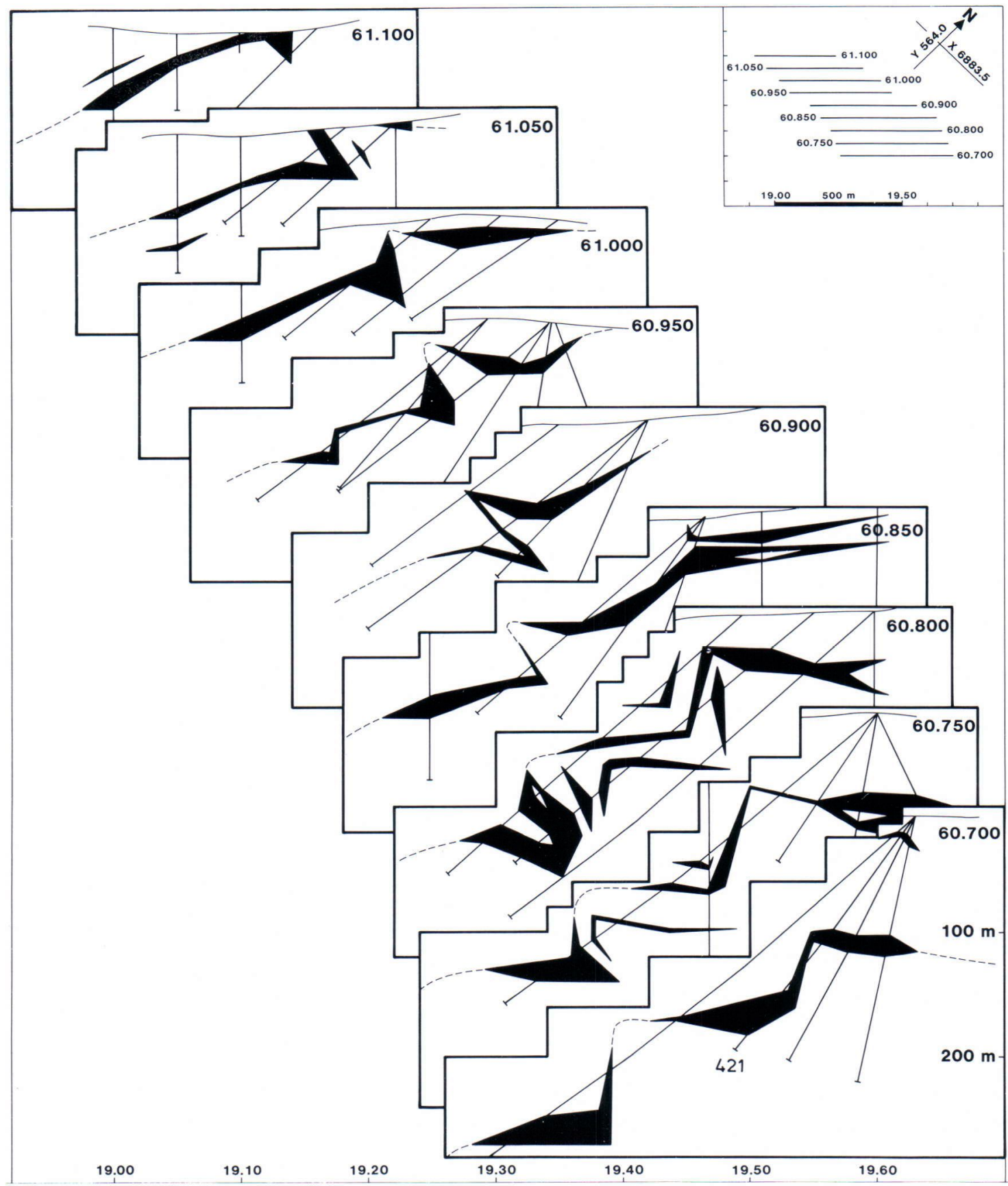

Fig. 4. Block diagram from Osikko 1 between profiles $\mathrm{L}=60.700$ and 61.100 . Black areas are ore sections in different profiles (cut off $0.5 \mathrm{~g} / \mathrm{t}$ ). The inset shows the location of the profiles. 
but $\mathrm{Au}$ contents are very low. The strongly sheared host rock has a more complicated ore mineralogy. In addition to the above types of disseminations the ore minerals comprise coarsegrained disseminations, compact veins and stringers. The most common ore minerals are pyrrhotite, arsenopyrite, löllingite, chalcopyrite and occasionally ilmenite or rutile, molybdenite and sphalerite. Pyrite, marcasite and some covellite occur as secondary minerals. In younger fractures and fissures there is some scheelite and powellite.

According to microscopical studies and microprobe analyses Au occurs as native gold and electrum grains in both sulphide and silicate phases. Au contents in the gold grains, especially in the silicate phase, are relatively high (over $95 \%$ ) and the $\mathrm{Ag}$ content ranges in electrum grains between $16.3-46.9 \%$. Electrum and gold mostly form fine-grained accumulations or rows in fractured arsenopyrite-löllingite grains. Often the Au minerals occur only as inclusions in the löllingite grains or at the contact of arsenopyrite and löllingite. Gold and electrum are always associated with Bi-bearing minerals having variable Se and $\mathrm{Te}$ contents (Fig. 5). Bi minerals are not $\mathrm{Au}$-bearing, but some $\mathrm{Hg}$, $\mathrm{Sb}$ and $\mathrm{S}$ may be present and native bismuth in particular may contain over $3 \mathrm{wt}-\% \mathrm{Hg}$.

\section{Geochemistry and alteration}

The diagram in Fig. 6 gives a good indication of $\mathrm{Au}$ in relation to other elements and lithologies. The highest Au contents are associated with high $\mathrm{S}$ and As in strongly sheared host rock. $\mathrm{As} / \mathrm{Au}$ ratio varies widely, whereas $\mathrm{Au} / \mathrm{Ag}$ ratio is always high, with the maximum $\mathrm{Ag}$ content in the bore hole samples being only $16 \mathrm{ppm}$. Gold has a good positive correlation coefficient $(0.84)$ with Bi (Fig. 7). Major element ratios in general are much the same in the Au occurrence and in the country rock, but a slight increase of $\mathrm{SiO}_{2} /$ $\mathrm{Al}_{2} \mathrm{O}_{3}$ and $\mathrm{K}_{2} \mathrm{O} / \mathrm{Na}_{2} \mathrm{O}$ ratios is associated with high $\mathrm{Au}$ contents (Fig. 6).

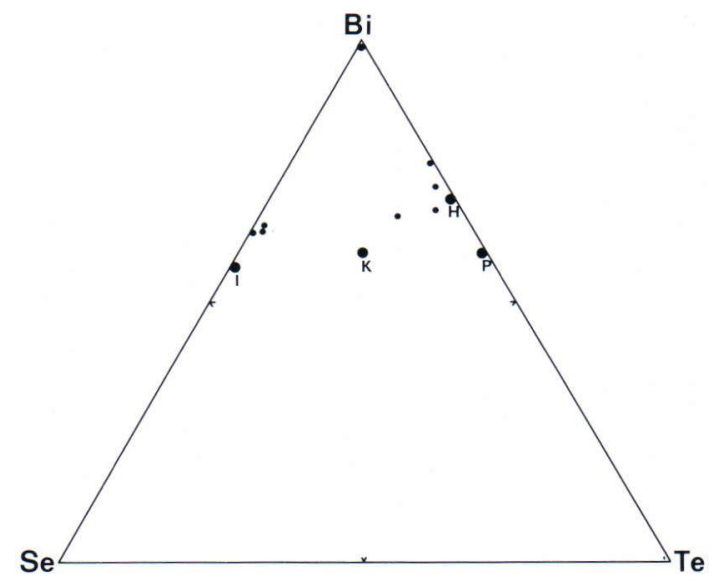

Fig. 5. Compositions of Bi-minerals in the Osikonmäki $\mathrm{Au}$ occurrence (small dots) and compositions of $\mathrm{I}=$ ikunolite, $\mathrm{K}=$ kawazulite, $\mathrm{P}=$ pilsenite, $\mathrm{H}=$ hedleyite after Ramdohr (1980).

The alteration of the host rock is mainly limited to the sheared and mineralized zone, but weak propylitic alteration is more widely distributed. Especially in the immediate vicinity of fractures there are some secondary epidote, carbonate, sericite, chlorite and diopside. The more intensive alteration of the mineralized rock is reflected also in the element contents and ratios shown in Fig. 6. Based on mineralogical considerations the most probable alteration processes are biotitization, weak silicification and potassic alteration. The modal compositions of the mineralized rock (Fig. 3) also indicate the partial replacement of oligoclase by microcline.

\section{Discussion}

Relatively few studies have been published about $\mathrm{Au}$ occurrences associated with Proterozoic granitoids. The studies in Canada summarized by Ayres and Cerný (1982), in Sweden e.g., by Öhlander (1986) and in Finland e.g., by Gaál \& Isohanni (1979), Nurmi et al. (1984), Nurmi (1985) and Nurmi \& Haapala (1986) treat mainly $\mathrm{Au}$-bearing $\mathrm{Cu}$ - or $\mathrm{Cu}-\mathrm{Mo}$-occurrences of 


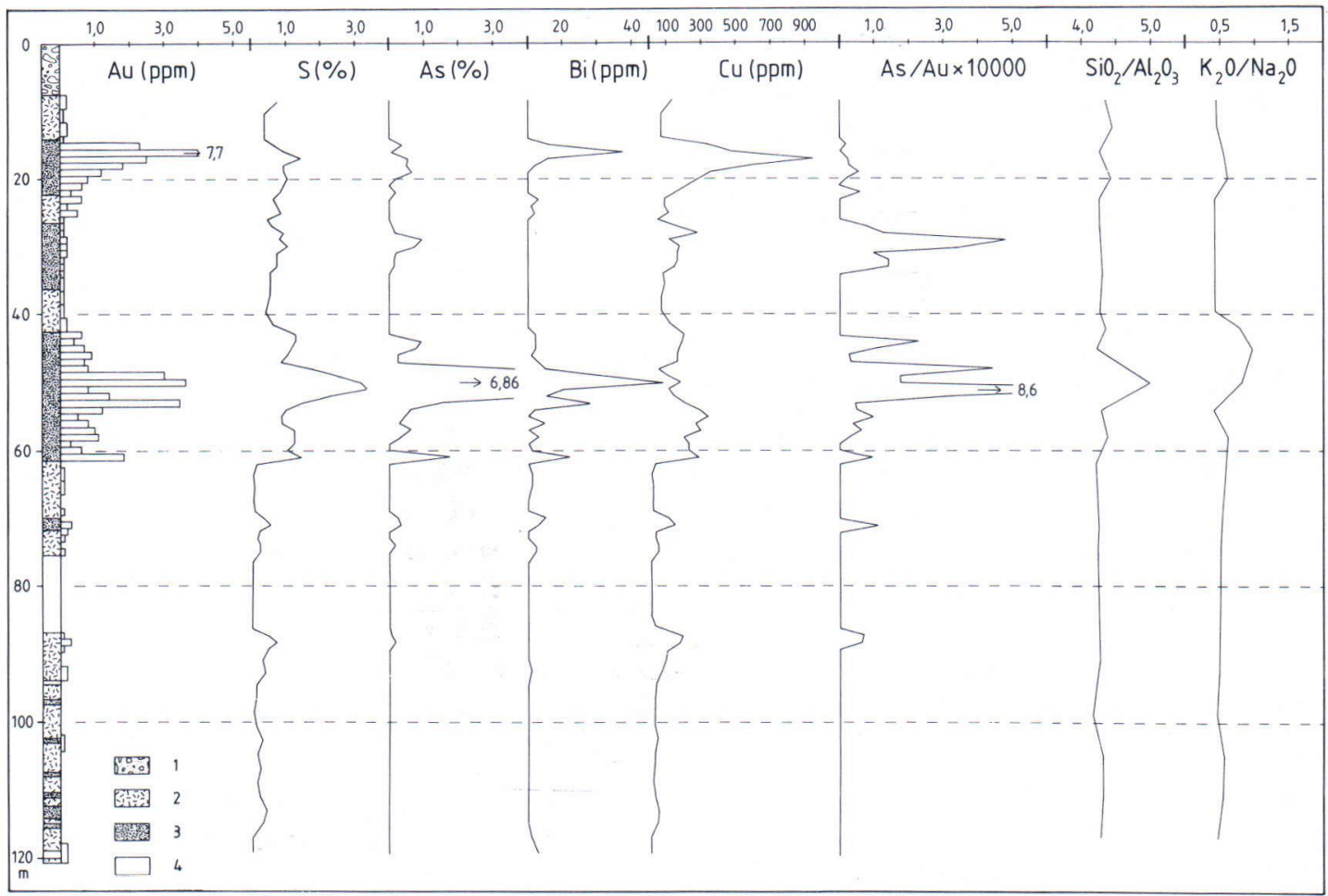

Fig. 6. Variation of some element contents and element ratios in bore hole 388 . Symbols: $1=$ overburden, $2=$ tonalite or granodiorite, 3 = sheared tonalite or granodiorite, $4=$ pegmatite.

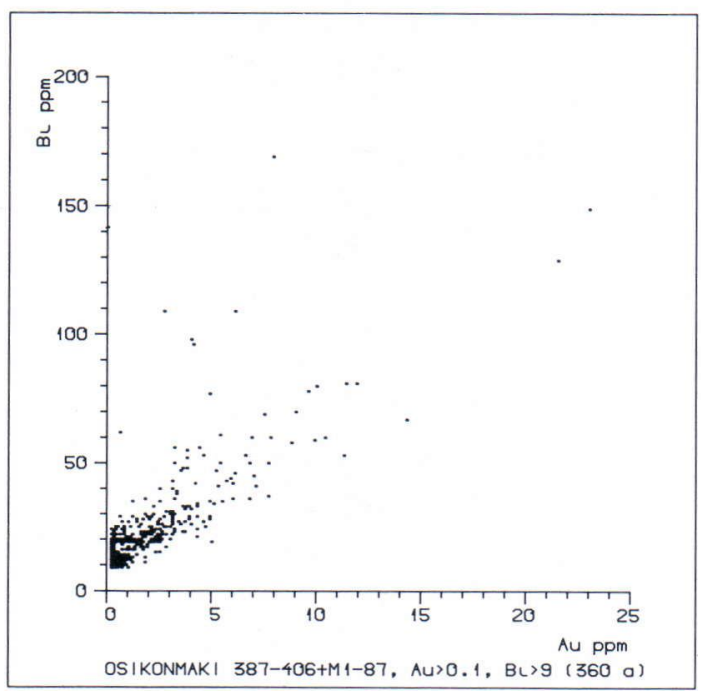

Fig. 7. Bi-Au diagram of samples having over $0.1 \mathrm{ppm} \mathrm{Au}$ and over 9 ppm $\mathrm{Bi}(\mathrm{n}=360)$. porphyry-type. Recently some Proterozoic veintype gold occurrences have been found in Finland and Sweden, too. E.g. gold deposits at I aivakangas (Mäkelä et al. 1988) and Björkdal (Bida 1989) are clearly associated with Proterozoic granitoids.

Because of the metamorphism and deformation of the Osikonmäki intrusion and Au occurrence it is difficult to make genetic conclusions although the host rock does have many petrological, structural and geochemical similarities with the synkinematic I-type granitoids hosting small porphyry-type occurrences, as described by Nurmi and Haapala (1986).

The occurrence has however clear indications of an epigenetic origin (Boyle 1979) for Au mineralization. Strong structural control (shearing and lineation), high $\mathrm{Au}$ /base-metal ratios, 
$\mathrm{Au} / \mathrm{Cu}=(0.003-0.060$

$\mathrm{Au} / \mathrm{Zn}=0.054-0.279$

$\mathrm{Au} / \mathrm{Pb}=0.072-0.856$,

ore mineralogy and rock alteration are typical of epigenetic mineralizations in shear zones (Groves et al. 1985).

The source of $\mathrm{Au}$ and hydrothermal fluids has been widely discussed. Magmatic (e.g., Ayres and Cerný 1982) and metamorphic secretion (e.g., Groves et al. 1985) theories are perhaps the most popular. In this case both the magmatic and metamorphic fluids may have been present. It is possible that gold originating from magmatic or/and metamorphic fluids has been precipitated, especially together with As- and Bi-bearing minerals, in the shear zone. During the D3-phase the shear zone has been deformed and recrystallized and gold has concentrated in structurally favourable places. More extensive lithogeo-

\section{References}

Ayres, L. D. \& Cerný, P., 1982. Metallogeny of granitoid rocks in the Canadian Shield. Can. Mineral. 20, 439-536.

Bida, J., 1989. The Björkdal gold project of Terra Mining AB-A new Swedish gold producer. Pp. 5-6 In New ore types in northern Fennoscandia. Luleå University of Technology, Luleå, Sweden, September 26-28, 1989. IGCP project 247. Abstracts, 1989.

Boyle, R. W., 1979. The geochemistry of gold and its deposits. Can. Geol. Surv., Bull. 280, 584 p.

Brown, G. C., 1982. Calc-alkaline intrusive rocks: their diversity, evolution, and relation to volcanic arcs. In R. S. Thorpe (Ed), Andesites, Orogenic Andesites and Related Rocks. John Wiley \& Sons, Chichester, 437-461.

Gaál, G., 1985. Nickel metallogeny related to tectonics. Geol. Surv. Finland, Bull. 333, 143-155.

-, 1986. 2200 million years of crustal evolution: The Baltic shield. Bull. Geol. Soc. Finland 58, 149-168.

—, \& Isohanni, M., 1979. Characteristics of igneous intrusions and various wall rocks in some Precambrian porphyry copper-molybdenum deposits in Pohjanmaa, Finland. Econ. Geol. 74 1198-1210.

Groves, D. I., Phillips, G. N., Ho, Susan E. \& Houston, Sarah M., 1985. The nature, genesis and regional controls of gold mineralization in Archean greenstone belts of the Western Australian Shield: A brief review. Trans. geol. Soc. S. Afr. 88, 135-148. chemical, isotope chemical and fluid inclusion studies may give more genetic information.

The Au occurrence of Osikonmäki has provided a good test of $\mathrm{Au}$ exploration methods. Boulder tracing is a very useful prospecting method in the area of drumlinoid forms. In the Osikonmäki area the geophysical IP-method gives good anomalies indicating sheared and more or less mineralized rock. For the till geochemistry, As may be a useful pathfinder for $\mathrm{Au}$ exploration on a regional and $\mathrm{Bi}$ on a local scale.

Acknowledgements. We are grateful to Prof. Gabor Gaál for his constructive comments on the manuscript. Discussions with Hannu Makkonen and Jyrki Parkkinen have been useful and the English of the manuscript has been corrected by Dr. Peter Ward. The typing was made by Mrs. Helena Saastamoinen and the figures were drawn by Mrs. Raija Väänänen. To all of them we are deeply grateful.

Kahma, A., 1973. The main metallogenic features of Finland. Geol. Surv. Finland, Bull. 265, 29 p.

Korsman, K., 1973. Pre-Quaternary rocks, Sheet 3233, Rantasalmi. Geological Map of Finland, 1:100 000.

-, Hölttä, P., Hautala, Tuula \& Wasenius, P., 1984. Metamorphism as an indicator of evolution and structure of the crust in eastern Finland. Geol. Surv. Finland, Bull. 328, 40 p.

—, \& Kilpeläinen, T., 1986. Relationship between zonal metamorphism and deformation in the Rantasalmi-Sulkava area, southeastern Finland. Geol. Surv. Finland, Bull. $339,33-42$.

—, Niemelä, R. \& Wasenius, P., 1988. Multistage evolution of the Proterozoic crust in the Savo schist belt, eastern Finland. Geol. Surv. Finland, Bull. 343, 89-96.

Kousa, J., 1985. Rantasalmen tholeiittisista ja komatiittisista vulkaniiteista. Summary: The tholeiitic and komatiitic metavolcanics in Rantasalmi, Southeastern Finland. Geologi 37 (2), 17-22.

Makkonen, H. \& Ekdahl, E., 1988. Petrology and structure of the early Proterozoic Pirilä gold deposit in southeastern Finland. Bull. Geol. Soc. Finland 60, 55-66.

Mäkelä, Merja, Sandberg, E. \& Rantala, O., 1988. Geochemical exploration of gold-bearing veins associated with granitoids in western Finland. Pp. 255-270 In Prospecting in Areas of Glaciated Terrain 1988. Proceedings of a Symposium sponsored by The Geology Division of CIM, Halifax, Nova Scotia, August 28-September 3, 1988. 
Nurmi, P. A., 1985. Lithogeochemistry in exploration for Proterozoic porphyry-type molybdenum and copper deposits, southern Finland. J. Geochem. Explor. 23, $163-191$.

-, Front, K., Lampio, E. \& Nironen, M., 1984. Etelä-Suomen svekokarjalaiset porfyyrityyppiset molybdeeni- ja kupariesiintymät, niiden granitoidi-isäntäkivet ja litogeokemiallinen etsintä. Summary: Svecokarelian porphyry-type molybdenum and copper occurrences in southern Finland: their granitoid host rocks and lithogeochemical exploration. Geol. Surv. Finland, Rep. Invest. $67,88 \mathrm{p}$.

—, \& Haapala, I., 1986. The Proterozoic granitoids of Finland: Granite types, metallogeny and relation to crustal evolution. Bull. Geol. Soc. Finland 58, 203-233.

Öhlander, B., 1986. Proterozoic mineralizations associated with granitoids in northern Sweden. 7th IAGOD symposium, Uppsala, Excursion guide no 7. SGU, Ser. Ca, no $65,39 \mathrm{p}$.
Ramdohr, P., 1980. The Ore Minerals and their Intergrowths. Pergamon Press Oxford and Akademie-Verlag, Berlin, $1207 \mathrm{p}$.

Ringwood, A.E., 1974. The petrological evolution of island arc systems. J. Geol. Soc. London 130, 183-204.

Simonen, A., 1980. The Precambrian in Finland. Geol. Surv. Finland, Bull. 304, 58 p.

Streckeisen, A. L., 1974. Classification and nomenclature of igneous rocks. Geol. Rundschau 63, 773-786.

White, A. J. R. \& Chappell, B. W., 1983. Granitoid types and their distribution in the Lachlan Fold Belt, southeastern Australia. Geol. Soc. Am., Mem. 159, 21-34.

Received October 18, 1989

Revision accepted February 15, 1990 